\title{
Meroterpenoids and Isocoumarinoids from a Myrothecium Fungus Associated with Apocynum venetum
}

\author{
Yanchao Xu ${ }^{1,2,3,+}$, Cong Wang ${ }^{2,4,+}$, Haishan Liu ${ }^{2}$, Guoliang Zhu ${ }^{2}$, Peng Fu ${ }^{2,3}$, Liping Wang 1,2,* \\ and Weiming $\mathrm{Zhu}{ }^{1,2,3, *}$ \\ 1 State Key Laboratory of Functions and Applications of Medicinal Plants, Guizhou Medical University, \\ Guiyang 550014, China; m18586818694@163.com \\ 2 Key Laboratory of Marine Drugs, Ministry of Education of China, School of Medicine and Pharmacy, \\ Ocean University of China, Qingdao 266003, China; wangcong123206@163.com(C.W.); \\ liuhaishan_229@outlook.com (H.L.); guoliangzhu2015@hotmail.com (G.Z.); fupeng@ouc.edu.cn (P.F.) \\ 3 Laboratory for Marine Drugs and Bioproducts, Qingdao National Laboratory for Marine Science and \\ Technology, Qingdao 266003, China \\ 4 Guangxi Key Laboratory of Chemistry and Engineering of Forest Products, School of Chemistry and \\ Chemical Engineering, Guangxi University for Nationalities, Nanning 530006, China \\ * Correspondence: lipingw2006@163.com (L.W.); weimingzhu@ouc.edu.cn (W.Z.); \\ Tel./Fax: +86-532-8203-1268 (W.Z.) \\ + These authors contributed equally to this paper.
}

Received: 31 August 2018; Accepted: 27 September 2018; Published: 1 October 2018

\begin{abstract}
Four new meroterpenoids 1-4 and four new isocoumarinoids 5-8, along with five known isocoumarinoids (9-13), were isolated from the fungus Myrothecium sp. OUCMDZ-2784 associated with the salt-resistant medicinal plant, Apocynum venetum (Apocynaceae). Their structures were elucidated by means of spectroscopic analysis, X-ray crystallography, ECD spectra and quantum chemical calculations. Compounds 1-5, 7, 9 and 10 showed weak $\alpha$-glucosidase inhibition with the $\mathrm{IC}_{50}$ values of $0.50,0.66,0.058,0.20,0.32,0.036,0.026$ and $0.37 \mathrm{mM}$, respectively.
\end{abstract}

Keywords: endophytic fungus; Myrothecium sp.; meroterpenoids; isocoumarinoids; $\alpha$-glucosidase inhibitors; salt-resistant plant; Apocynum venetum

\section{Introduction}

Since the discovery of penicillin, fungi have been an important source of lead compounds for drug development, which have provided a lot of attractive natural products (NPs) with different biological activities [1-3]. With the increase of study on the terrestrial fungal NPs, more and more known compounds were isolated repeatedly. Therefore, many researchers turned their attention to the fungi isolated from specific habitats, such as the marine-derived fungi [4-7] and the fungi associated with the plants or animals [8-11].

As part of our ongoing studies to search for bioactive NPs from fungi derived from special niche [12-16], we screened the fungus Myrothecium sp. OUCMDZ-2784 which is associated with the salt-resistant plant $A$. venetum (Apocynaceae) growing in the Yellow River Delta, a traditional Chinese medicine used for treatment of hypertension [17] and heart failure [18]. Myrothecium sp. has been reported to produce trichothecenes [19], sesquiterpenes [20,21], diterpenes [22] and cyclopeptides [23] with cytotoxic and antibacterial activities. The ethyl acetate (EtOAc) extract of the fermentation of Myrothecium sp. OUCMDZ-2784 showed 75\% inhibition of $\alpha$-glucosidase at $286 \mu \mathrm{g} / \mathrm{mL}$. Chemical study resulted in the isolation and identification of four new meroterpenoids, myrothecisins A-D (1-4) and four new 
isocoumarinoids, myrothelactones A-D (5-8), together with five known isocoumarinoids that were identified as tubakialactone B (9) [24], acremonone G (10) [25], 6,8-dihydroxy-3-methylisocoumarin (11) [26], 3,4-dimethyl-6,8-dihydroxyisocoumarin (12) [27] and sescandelin B (13) [28], respectively by comparing ${ }^{1} \mathrm{H}$ and ${ }^{13} \mathrm{C}$ NMR spectra (Figure S57, Table S1) as well as ESIMS spectra (Figure S59) with those reported.

\section{Results and Discussion}

Myrothecisin A (1) was isolated as a pale-yellow oil. Its molecular formula was assigned as $\mathrm{C}_{25} \mathrm{H}_{34} \mathrm{O}_{7}$ by the HRESIMS peak at $m / z 469.2188[\mathrm{M}+\mathrm{Na}]^{+}$(Figure S58A), indicating nine degrees of unsaturation. The ${ }^{13} \mathrm{C}$ NMR (Figure S6) spectrum of 1 showed 25 signals that were classified by DEPT (Figure S7) and HSQC (Figure S8) as an aldehyde carbonyl carbon $\left(\delta_{C} 193.8\right)$, one acyl carbonyl carbon $\left(\delta_{C} 170.3\right)$, five $\mathrm{sp}^{2}$ non-protonated carbons $\left(\delta_{C} 167.3,159.8,149.5,112.3,111.2\right)$ and three $\mathrm{sp}^{3}$ non-protonated carbons $\left(\delta_{C} 98.8,42.8,39.2\right)$, one $\mathrm{sp}^{2}$ methine $\left(\delta_{\mathrm{C}} 101.5\right)$ and four $\mathrm{sp}^{3}$ methines $\left(\delta_{C} 78.2,71.4,45.6,36.0\right)$, five $\mathrm{sp}^{3}$ methylenes $\left(\delta_{C} 60.5,35.1,30.6,30.4,20.7\right)$ and five methyl carbons $\left(\delta_{C} 28.7,21.3,17.0,16.6,15.2\right)$ (Table 1$)$. The ${ }^{1} \mathrm{H}$ (Figure S5) and HSQC NMR showed the singlet signals at $\delta_{\mathrm{H}} 10.06$ and 6.56 for an aldehyde proton and an aromatic proton, respectively. The key HMBC (Figure S10) correlations from H-7' $\left(\delta_{\mathrm{H}} 10.06\right)$ to C-2' $/ \mathrm{C}-3^{\prime} / \mathrm{C}-4^{\prime}, 2^{\prime}-\mathrm{OH}\left(\delta_{\mathrm{H}} 12.16\right)$ to $\mathrm{C}-1^{\prime} / \mathrm{C}-2^{\prime} / \mathrm{C}-3^{\prime}, \mathrm{H}-5^{\prime}\left(\delta_{\mathrm{H}} 6.56\right)$ to $\mathrm{C}-1^{\prime} / \mathrm{C}-4^{\prime} / \mathrm{C}-6^{\prime} / \mathrm{C}-8^{\prime}, \mathrm{H}-8^{\prime}\left(\delta_{\mathrm{H}} 4.74\right)$ to $\mathrm{C}-3^{\prime} / \mathrm{C}-4^{\prime} / \mathrm{C}-5^{\prime}$ and $8^{\prime}-\mathrm{OH}\left(\delta_{\mathrm{H}}\right.$ $5.44)$ to $\mathrm{C}-4^{\prime} / \mathrm{C}-8^{\prime}$ suggested a penta-substituted benzene ring (Figure 2). The COSY (homonuclear correlation spectroscopy) correlations from $\mathrm{H}-1$ through $\mathrm{H}-2$ to $\mathrm{H}-3$ and $\mathrm{H}-5$ through $\mathrm{H}-6, \mathrm{H}-7$ and $\mathrm{H}-8$ to $\mathrm{H}-12$ (Figure 1 and Figure S9), along with the key HMBC correlations from $\mathrm{H}-2$ to C-4/C-10/C-16, $\mathrm{H}-3$ to C-5/C-13/C-14, 3-OH to C-2/C-3/C-4, H-1 to C-2/C-3/C-10/C-15, H-15 to C-1/C-5/C-9/C-10, $\mathrm{H}-5$ to $\mathrm{C}-3 / \mathrm{C}-4 / \mathrm{C}-6 / \mathrm{C}-13, \mathrm{H}-6$ to $\mathrm{C}-5, \mathrm{H}-7$ to C-8, H-13 to C-3/C-5/C-14, H-14 to C-3/C-5/C-13, $\mathrm{H}-12$ to $\mathrm{C}-7 / \mathrm{C}-8 / \mathrm{C}-9$ and $\mathrm{H}-17$ to $\mathrm{C}-16$ revealed a sesquiterpene fragment (Figure 2). The connection of the above-mentioned two fragments were confirmed by the key HMBC correlations from $\mathrm{H}-11$ to C-8/C-9/C-10/C-1'/C-2' /C-6' (Figure 2) [29]. The relative configuration of 1 was determined by the NOESY correlations from H-8 to H-11 and H-15, H-3 to H-5 and H-13, H-2 to H-14 and H-15 and H-11 to H-15 (Figure 3 and Figure S11). The absolute configuration of 1 was determined by calculation of electronic circular dichroism (ECD) using time-dependent density functional theory (TDDFT) (Figure S1) $[30,31]$ and the measured ECD spectrum of 1 matched well with the calculated ECD spectrum for $(2 R, 3 R, 5 S, 8 R, 9 R, 10 S)-\mathbf{1}$ (Figure 4$)$.
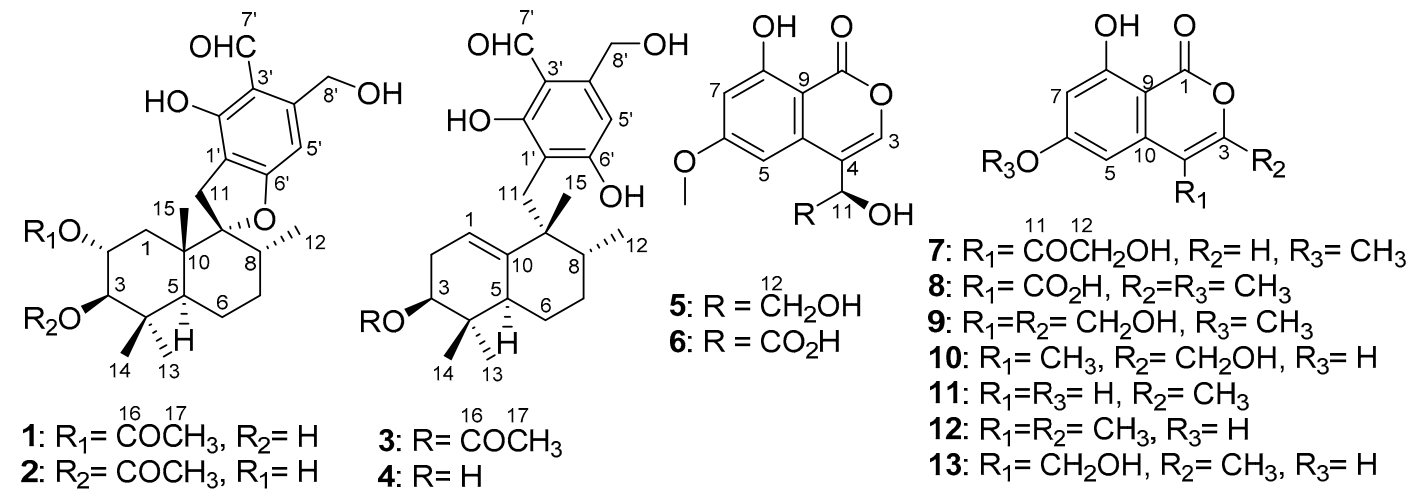

Figure 1. Structures 1-13 isolated from Myrothecium sp. OUCMDZ-2784.

The molecular formula of 2 was also determined as $\mathrm{C}_{25} \mathrm{H}_{34} \mathrm{O}_{7}$ by the HRESIMS peak at $\mathrm{m} / \mathrm{z}$ $469.2200[\mathrm{M}+\mathrm{Na}]^{+}$(Figure S58B), implying that 2 is an isomer of 1 . Comparison of its ${ }^{1} \mathrm{H}$ and ${ }^{13} \mathrm{C}$ NMR spectra (Figures S12-S16) with those of 1 revealed that the acetyloxy group in 2 was on C-3. This was confirmed by the HMBC (Figure S17) correlation from H-3 $\left(\delta_{\mathrm{H}} 4.29\right)$ to C-16 $\left(\delta_{\mathrm{C}} 170.3\right)$ (Figure 2). The similar NOESY correlations (Figure 3 and Figure S18) suggested that 2 has the same relative configuration as $\mathbf{1}$. The similarity of ECD curves between $\mathbf{2}$ and $\mathbf{1}$ (Figure 5) indicated the same absolute configurations of its stereogenic carbons. Therefore 2 was named myrothecisin $B$. 
Table 1. ${ }^{1} \mathrm{H}(600 \mathrm{MHz})$ and ${ }^{13} \mathrm{C}(150 \mathrm{MHz}) \mathrm{NMR}$ data for 1-4 in DMSO- $d_{6}$.

\begin{tabular}{|c|c|c|c|c|c|c|c|c|}
\hline \multirow{2}{*}{ No. } & \multicolumn{2}{|r|}{1} & \multicolumn{2}{|r|}{2} & \multicolumn{2}{|r|}{3} & \multicolumn{2}{|r|}{4} \\
\hline & $\delta_{C}$, Type & $\delta_{\mathrm{H}}$, Mult. $(J$ in Hz) & $\delta_{C}$, Type & $\delta_{\mathrm{H}}$, Mult. $(J$ in $\mathrm{Hz})$ & $\delta_{C}$, Type & $\delta_{\mathrm{H}}$, Mult. $(J$ in $\mathrm{Hz})$ & $\delta_{C}$, Type & $\delta_{\mathrm{H}}$, Mult. $(J$ in $\mathrm{Hz})$ \\
\hline 1 & $35.1, \mathrm{CH}_{2}$ & $1.16, \mathrm{~m} ; 1.55^{\mathrm{a}}$ & $38.4, \mathrm{CH}_{2}$ & $1.17, \mathrm{~m} ; 1.57^{\mathrm{a}}$ & $114.7, \mathrm{CH}$ & 4.94, brs & $116.3, \mathrm{CH}$ & $4.88, \mathrm{~s}$ \\
\hline 2 & $71.4, \mathrm{CH}$ & $4.83, \operatorname{ddd}(11.5,10.1,4.1)$ & $64.4, \mathrm{CH}$ & $3.65, \mathrm{~m}$ & $28.0, \mathrm{CH}_{2}$ & $1.89, \mathrm{~m} ; 1.23, \mathrm{~m}$ & $31.6, \mathrm{CH}_{2}$ & $1.72, \mathrm{~m}$ \\
\hline 3 & $78.2, \mathrm{CH}$ & $2.96, \mathrm{dd}(10.1,4.8)$ & $83.3, \mathrm{CH}$ & $4.29, \mathrm{~d}(9.9)$ & $75.6, \mathrm{CH}$ & $4.62, \mathrm{dd}(8.6,6.5)$ & $71.5, \mathrm{CH}$ & $3.30^{\mathrm{a}}$ \\
\hline 4 & $39.2, \mathrm{C}$ & & $39.0, \mathrm{C}$ & & $35.6, \mathrm{C}$ & & $36.9, \mathrm{C}$ & \\
\hline 5 & $45.6, \mathrm{CH}$ & $1.56^{\mathrm{a}}$ & $45.5, \mathrm{CH}$ & $1.63^{\mathrm{a}}$ & $43.1, \mathrm{CH}$ & $2.54, \mathrm{~m}$ & $43.7, \mathrm{CH}$ & $2.45, \mathrm{~m}$ \\
\hline 6 & $20.7, \mathrm{CH}_{2}$ & $1.54^{\mathrm{a}} ; 1.47, \mathrm{~m}$ & $20.4, \mathrm{CH}_{2}$ & $1.56^{\mathrm{a}} ; 1.48, \mathrm{~m}$ & 26.7, $\mathrm{CH}_{2}$ & $1.79, \mathrm{~m}$ & 26.7, $\mathrm{CH}_{2}$ & $1.77, \mathrm{~m}$ \\
\hline 7 & $30.6, \mathrm{CH}_{2}$ & $1.55^{\mathrm{a}} ; 1.35, \mathrm{~m}$ & $30.5, \mathrm{CH}_{2}$ & $1.57^{\mathrm{a}} ; 1.38, \mathrm{~m}$ & $30.2, \mathrm{CH}_{2}$ & $1.54, \mathrm{~m}$ & $30.3, \mathrm{CH}_{2}$ & $1.52, \mathrm{~m}$ \\
\hline 8 & $36.0, \mathrm{CH}$ & $1.83, \mathrm{~m}$ & $35.6, \mathrm{CH}$ & $1.85, \mathrm{~m}$ & $43.3, \mathrm{CH}$ & $1.30, \mathrm{~m}$ & $42.9, \mathrm{CH}$ & $1.29, \mathrm{~m}$ \\
\hline 9 & $98.8, \mathrm{C}$ & & $98.8, \mathrm{C}$ & & 43.7, C & & $43.7, \mathrm{C}$ & \\
\hline 10 & $42.8, \mathrm{C}$ & & $42.5, \mathrm{C}$ & & $143.9, \mathrm{C}$ & & 143.0, C & \\
\hline 11 & $30.4, \mathrm{CH}_{2}$ & $\begin{array}{l}3.03, \mathrm{~d}(16.1) \\
2.79, \mathrm{~d}(16.0)\end{array}$ & $30.2, \mathrm{CH}_{2}$ & $\begin{array}{l}\text { 3.11, d (16.5); } \\
2.81, \mathrm{~d}(16.5)\end{array}$ & 23.5, $\mathrm{CH}_{2}$ & $\begin{array}{l}\text { 2.68, d (12.9); } \\
\text { 2.53, d (12.9) }\end{array}$ & 23.3, $\mathrm{CH}_{2}$ & $\begin{array}{l}\text { 2.63, d (12.7); } \\
\text { 2.50, d (12.7) }\end{array}$ \\
\hline 12 & $15.2, \mathrm{CH}_{3}$ & $0.64, \mathrm{~d}(6.3)$ & $15.1, \mathrm{CH}_{3}$ & $0.68, \mathrm{~d}(6.3)$ & $17.1, \mathrm{CH}_{3}$ & $1.03, \mathrm{~d}(6.6)$ & $17.2, \mathrm{CH}_{3}$ & $1.02, \mathrm{~d}(6.7)$ \\
\hline 13 & 28.7, $\mathrm{CH}_{3}$ & $0.97, \mathrm{~s}$ & $28.4, \mathrm{CH}_{3}$ & $0.79, \mathrm{~s}$ & $25.0, \mathrm{CH}_{3}$ & $0.88, \mathrm{~s}$ & $25.2, \mathrm{CH}_{3}$ & $0.95, \mathrm{~s}$ \\
\hline 14 & 17.0, $\mathrm{CH}_{3}$ & $0.78, \mathrm{~s}$ & $17.5, \mathrm{CH}_{3}$ & $0.81, \mathrm{~s}$ & $17.1, \mathrm{CH}_{3}$ & $0.73, \mathrm{~s}$ & $14.8, \mathrm{CH}_{3}$ & $0.59, \mathrm{~s}$ \\
\hline 15 & $16.6, \mathrm{CH}_{3}$ & $1.04, \mathrm{~s}$ & $16.6, \mathrm{CH}_{3}$ & $1.03, \mathrm{~s}$ & 23.0, $\mathrm{CH}_{3}$ & $0.96, \mathrm{~s}$ & $22.9, \mathrm{CH}_{3}$ & $0.91, \mathrm{~s}$ \\
\hline 16 & $170.3, \mathrm{C}$ & & $170.3, \mathrm{C}$ & & $169.8, \mathrm{C}$ & & & \\
\hline 17 & $21.3, \mathrm{CH}_{3}$ & $1.91, \mathrm{~s}$ & 21.0, $\mathrm{CH}_{3}$ & $2.02, \mathrm{~s}$ & 21.0, $\mathrm{CH}_{3}$ & $1.98, \mathrm{~s}$ & & \\
\hline $1^{\prime}$ & $111.2, \mathrm{C}$ & & 111.2, C & & $111.4, \mathrm{C}$ & & 111.3, C & \\
\hline $2^{\prime}$ & $159.8, \mathrm{C}$ & & $159.8, \mathrm{C}$ & & $164.5, \mathrm{C}$ & & $164.8, \mathrm{C}$ & \\
\hline $3^{\prime}$ & $112.3, \mathrm{C}$ & & $112.2, \mathrm{C}$ & & $110.2, \mathrm{C}$ & & $110.2, \mathrm{C}$ & \\
\hline $4^{\prime}$ & $149.5, \mathrm{C}$ & & $149.4, \mathrm{C}$ & & $145.4, \mathrm{C}$ & & $145.4, \mathrm{C}$ & \\
\hline $5^{\prime}$ & $101.5, \mathrm{CH}$ & $6.56, \mathrm{~s}$ & 101.6, CH & $6.61, \mathrm{~s}$ & $107.5, \mathrm{CH}$ & $6.51, \mathrm{~s}$ & $107.3, \mathrm{CH}$ & $6.50, \mathrm{~s}$ \\
\hline $6^{\prime}$ & 167.3, C & & 167.3, C & & $164.6, \mathrm{C}$ & & 164.6, C & \\
\hline $7^{\prime}$ & $193.8, \mathrm{CH}$ & $10.06, \mathrm{~s}$ & $193.8, \mathrm{CH}$ & $10.07, \mathrm{~s}$ & 193.3, CH & $9.96, \mathrm{~s}$ & $193.4, \mathrm{CH}$ & $9.96, \mathrm{~s}$ \\
\hline $8^{\prime}$ & $60.5, \mathrm{CH}_{2}$ & $4.74, \mathrm{~s}$ & $60.4, \mathrm{CH}_{2}$ & $4.74, \mathrm{~s}$ & $59.9, \mathrm{CH}_{2}$ & $4.70, \mathrm{~s}$ & $59.8, \mathrm{CH}_{2}$ & $4.70, \mathrm{~s}$ \\
\hline 2/3-OH & & 4.94, d (4.7) & & $4.62, \mathrm{~d}(4.9)$ & & & & $4.13, \mathrm{~s}$ \\
\hline $2^{\prime}-\mathrm{OH}$ & & $12.16, \mathrm{~s}$ & & $12.24, \mathrm{~s}$ & & $12.84, \mathrm{~s}$ & & $12.78, \mathrm{~s}$ \\
\hline $6^{\prime}-\mathrm{OH}$ & & & & & & & & 10.55, brs \\
\hline $8^{\prime}-\mathrm{OH}$ & & $5.44, \mathrm{~s}$ & & $5.39, \mathrm{~s}$ & & $5.35, \mathrm{~s}$ & & $5.36, \mathrm{~s}$ \\
\hline
\end{tabular}


Compound 3 was also obtained as a pale-yellow oil. Its molecular formula was determined as $\mathrm{C}_{25} \mathrm{H}_{34} \mathrm{O}_{6}$ according to the HRESIMS peak at $\mathrm{m} / \mathrm{z} 453.2238[\mathrm{M}+\mathrm{Na}]^{+}$(Figure S58C). The ${ }^{13} \mathrm{C}$ NMR (Figure S20) spectrum of 3 showed one aldehyde carbonyl carbon $\left(\delta_{C} 193.3\right)$, one acyl carbonyl carbon $\left(\delta_{C} 169.8\right)$, six sp ${ }^{2}$ non-protonated carbons $\left(\delta_{C} 164.6,164.5,145.4,143.9,111.4,110.2\right)$ and two $\mathrm{sp}^{3}$ non-protonated carbons $\left(\delta_{C} 43.7,35.6\right)$, two sp $p^{2}$ methines $\left(\delta_{C} 114.7,107.5\right)$ and three $\mathrm{sp}^{3}$ methines $\left(\delta_{C}\right.$ $75.6,43.3,43.1)$, five $\mathrm{sp}^{3}$ methylenes $\left(\delta_{C} 59.9,30.2,28.0,26.7,23.5\right)$ and five methyl carbons $\left(\delta_{C} 25.0\right.$, 23.0, 21.0, 17.1, 17.1) (Table 1). Analysis of its 1D and 2D NMR (Figures S19-S24) data revealed the presence of a substituted benzene ring and a sesquiterpene unit, indicating $\mathbf{3}$ was an analogue of $\mathbf{1}$ and 2. Comparison of the ${ }^{1} \mathrm{H}$ and ${ }^{13} \mathrm{C}$ NMR spectra with those of $\mathbf{1}$ and $\mathbf{2}$ suggested a same pentasubstituted benzene ring. The structure of the sesquiterpene unit was slightly modified and was determined by the COSY (Figure S23) correlations from $\mathrm{H}-1$ through $\mathrm{H}-2$ to $\mathrm{H}-3$ and $\mathrm{H}-5$ through $\mathrm{H}-6, \mathrm{H}-7$ and $\mathrm{H}-8$ to $\mathrm{H}-12$ and the key HMBC (Figure S24) correlations from H-3 to C-2/C-4/C-10/C-13/C-14, H-17 to C-16, H-1 to C-3/C-9, H-15 to C-10, H-8 to C-9, H-5 to C-9/C-13, H-12 to C-7 and H-2 to C-4/C-10 (Figure 2). The HMBC correlations from $\mathrm{H}_{2}-11\left(\delta_{\mathrm{H}} 2.68 / 2.53\right)$ to C-8/C-10/C-15/C-2' /C-6' (Figure 2) confirmed the connection between the sesquiterpene fragment and the benzene ring. The relative configuration of 3 was determined by the NOESY (Figure S25) correlations from H-13 to H-3 and H-5, H-8 to H-15, as well as $\mathrm{H}-5$ to $\mathrm{H}-11$ (Figure 3). The absolute configuration was determined as $(3 S, 5 R, 8 R, 9 R)$ - by comparison of the calculated and experimental ECD spectra (Figure 4 and Figure S2). Therefore 3 was named myrothecisin $\mathrm{C}$.

The molecular formula of 4 was assigned as $\mathrm{C}_{23} \mathrm{H}_{32} \mathrm{O}_{5}$ by the HRESIMS peak at $m / z 411.2139$ [M + $\mathrm{Na}]^{+}$(Figure S58D), which was $\mathrm{C}_{2} \mathrm{H}_{2} \mathrm{O}$ less than that of 3 . The similarity of the UV and NMR data between 3 and 4 (Table 1) suggested that 4 possesses the same skeleton as 3 . Careful comparison of their ${ }^{1} \mathrm{H}$ and ${ }^{13} \mathrm{C}$ NMR spectra (Figures S26-S31) showed that the acetyloxy group $\left(\delta_{\mathrm{C}} 21.0 / \delta_{\mathrm{H}} 1.98\right.$ and $\left.\delta_{C} 169.8\right)$ in 3 was replaced by a hydroxy group $\left(\delta_{H} 4.13\right)$ in 4 (Table 1). The NOESY data (Figure 3 and Figure S32) suggested that 4 has the same relative configuration as 3 . The ECD Cotton effects of 4 were nearly identical to those of 3 (Figure 5), indicating the same absolute configurations of the corresponding stereogenic carbons. Thus, 4 was named myrothecisin D.
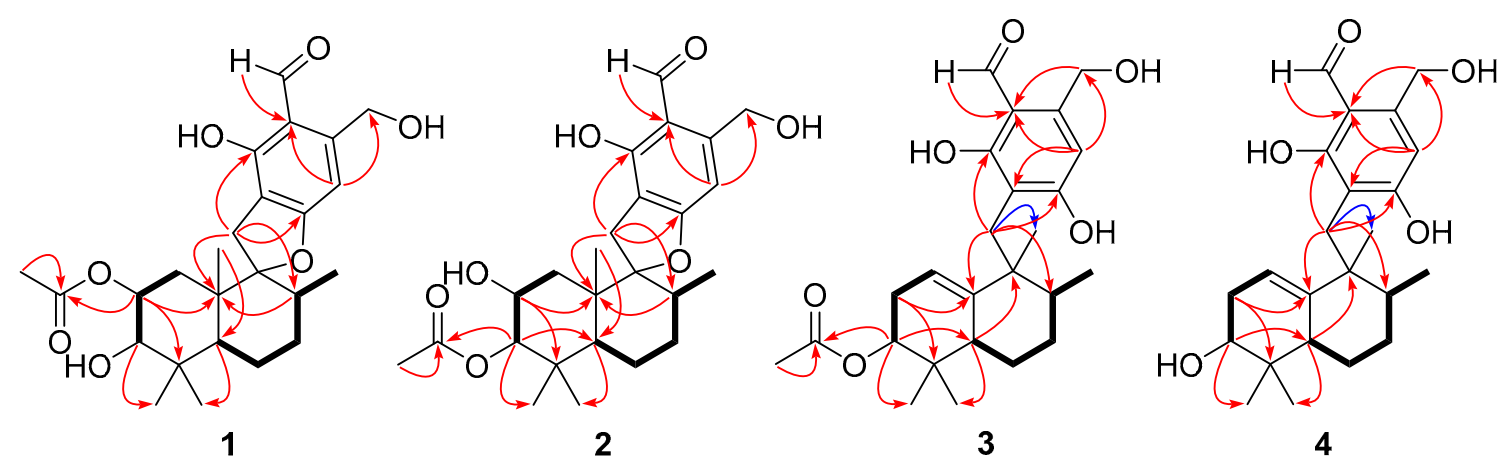

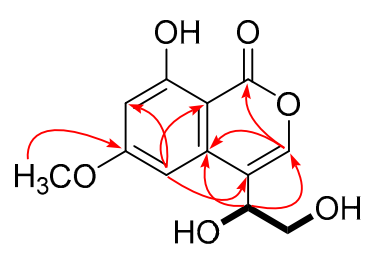

5

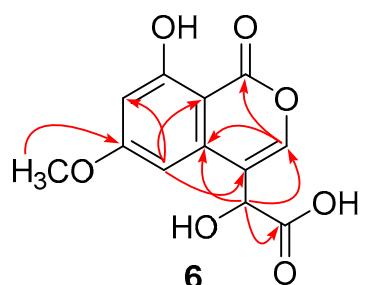

6

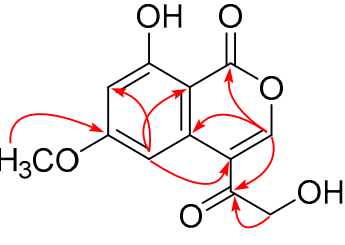

7

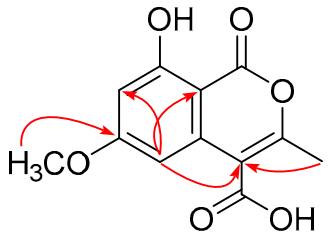

8

Figure 2. Key homonuclear correlation spectroscopy (COSY) and key HMBC correlations for 1-8. 

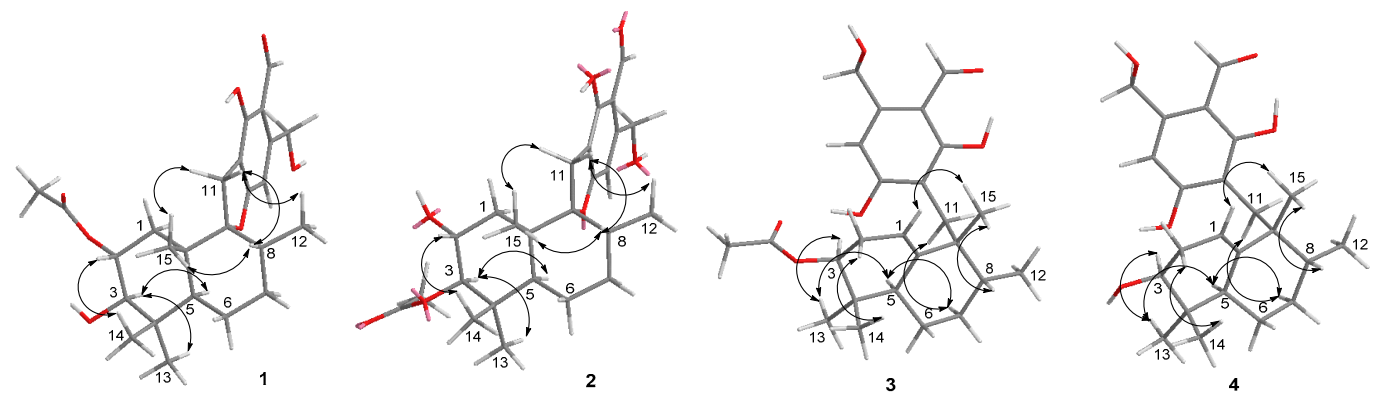

Figure 3. NOESY correlations for 1-4.

Compound 5 was obtained as a colorless crystal with the molecular formula $\mathrm{C}_{12} \mathrm{H}_{12} \mathrm{O}_{6}$ from the HRESIMS peak at $m / z 251.0563[\mathrm{M}-\mathrm{H}]^{-}$(Figure S58E). The ${ }^{1} \mathrm{H}$ NMR spectrum showed two meta-coupled aromatic protons at $\delta_{\mathrm{H}} 6.78(\mathrm{~d}, J=2.2 \mathrm{~Hz})$ and $\delta_{\mathrm{H}} 6.63(\mathrm{~d}, J=2.2 \mathrm{~Hz})($ Table 2, Figure S33), indicating the presence of a tetra-substituted benzene ring. The ${ }^{13} \mathrm{C}$ (Figure S34) NMR spectrum showed 12 carbon signals that were classified by DEPT (Figure S35) and HSQC (Figure S36) spectra as six sp ${ }^{2}$ non-protonated carbons $\left(\delta_{C} 166.4,165.4,163.4,137.6,118.6,99.9\right)$, three sp ${ }^{2}$ methines $\left(\delta_{C} 143.1\right.$, $100.5,100.4)$ and one $\mathrm{sp}^{3}$ methine $\left(\delta_{C} 68.8\right)$, one sp ${ }^{3}$ methylene $\left(\delta_{C} 64.8\right)$ and one methoxy group $\left(\delta_{C}\right.$ 56.0) (Table 2). The key HMBC correlations (Figure 2 and Figure S38) from $\mathrm{CH}_{3} \mathrm{O}-6$ to $\mathrm{C}-6, \mathrm{HO}-11$ to C-4/C-12, H-11 to C-3/C-10, H-3 to C-1/C-10, H-5 to C-4/C-7/C-9 and H-7 to C-9 along with the continuous COSY correlations of HO- $11\left(\delta_{\mathrm{H}} 5.50\right) / \mathrm{H}-11\left(\delta_{\mathrm{H}} 4.66\right) / \mathrm{H}-12\left(\delta_{\mathrm{H}} 3.51,3.62\right) / \mathrm{HO}-12\left(\delta_{\mathrm{H}}\right.$ 4.81) (Figure S37) revealed that 5 possesses a 4,6,8-trisubstituted isocoumarin skeleton with a hydroxy, a methoxy and a 1,2-dihydroxy ethyl at C-8, C-6 and C-4, respectively. The structure of 5 was further confirmed by $X$-ray crystallography (Figure 6). Because the value of the Flack parameter [-0.2(2)] was large, the absolute configuration determined by X-ray crystallography was not reliable. Thus, the ECD calculation method was used to further confirm the absolute configuration of C-11 of 5 as 11R- (Figure 4 and Figure S3). Consequently, 5 was named myrothelactone A.

Compound 6 was obtained as a white powder. Its molecular formula was determined as $\mathrm{C}_{12} \mathrm{H}_{10} \mathrm{O}_{7}$ based on the HRESIMS peak at $\mathrm{m} / z 265.0355[\mathrm{M}-\mathrm{H}]^{-}$(Figure S58F). The UV and ${ }^{13} \mathrm{C}$ NMR data of 6 (Table 2) were similar to those of 5 , indicating that they have the same isocoumarin scaffold. Comparison of their ${ }^{1} \mathrm{H}$ and ${ }^{13} \mathrm{C}$ data (Figures S39-S43) indicated that the hydroxymethyl group $\left(\delta_{\mathrm{C} / \mathrm{H}}\right.$ $\left.64.8 / 3.62 \& 3.51, \delta_{\mathrm{H}} 4.81\right)$ in 5 was replaced by the carboxyl group $\left(\delta_{\mathrm{C}} 173.4\right)$. This change was verified by the key HMBC (Figure S44) correlations from H-11 to C-3/C-10/C-12. The absolute configuration of C-11 of 6 was determined as $11 R$ - by comparison of the calculated and experimental ECD spectra (Figure 4 and Figure S4). Therefore, 6 was name myrothelactone B. 
Table 2. ${ }^{1} \mathrm{H}$ and ${ }^{13} \mathrm{C}$ NMR data for 5-8 in DMSO- $d_{6}$.

\begin{tabular}{|c|c|c|c|c|c|c|c|c|}
\hline \multirow{2}{*}{ No. } & \multicolumn{2}{|r|}{$5^{a}$} & \multicolumn{2}{|r|}{$6^{b}$} & \multicolumn{2}{|r|}{$7^{b}$} & \multicolumn{2}{|r|}{$8^{b}$} \\
\hline & $\delta_{C}$, Type & $\delta_{\mathrm{H}}$, mult. $(J$ in $\mathrm{Hz})$ & $\delta_{C}$, Type & $\delta_{\mathrm{H}}$, mult. $(J$ in $\mathrm{Hz})$ & $\delta_{C}$, Type & $\delta_{\mathrm{H}}$, mult. $(J$ in $\mathrm{Hz})$ & $\delta_{C}$, Type & $\delta_{\mathrm{H}}$, mult. $(J$ in $\mathrm{Hz})$ \\
\hline 1 & $165.4, \mathrm{C}$ & & $164.9, \mathrm{C}$ & & $163.4, \mathrm{C}$ & & $165.2, \mathrm{C}$ & \\
\hline 3 & 143.1, CH & $7.45, \mathrm{~s}$ & $144.4, \mathrm{CH}$ & $7.62, \mathrm{~s}$ & $153.1, \mathrm{CH}$ & $8.47, \mathrm{~s}$ & $151.0, \mathrm{C}$ & \\
\hline 4 & $118.6, \mathrm{C}$ & & $117.7, \mathrm{C}$ & & $114.7, \mathrm{C}$ & & $118.7, \mathrm{C}$ & \\
\hline 5 & $100.5, \mathrm{CH}$ & $6.78, \mathrm{~d}(2.2)$ & 101.6, $\mathrm{CH}$ & $6.84, \mathrm{~s}$ & $102.3, \mathrm{CH}$ & $7.46, \mathrm{~s}$ & 101.6, $\mathrm{CH}$ & $6.86, \mathrm{~s}$ \\
\hline 6 & $166.4, \mathrm{C}$ & & $166.4, \mathrm{C}$ & & $166.8, \mathrm{C}$ & & $166.3, \mathrm{C}$ & \\
\hline 7 & $100.4, \mathrm{CH}$ & $6.63(\mathrm{~d}, 2.2)$ & $100.6, \mathrm{CH}$ & $6.63, \mathrm{~s}$ & $101.2, \mathrm{CH}$ & $6.68, \mathrm{~s}$ & $99.8, \mathrm{CH}$ & $6.48, \mathrm{~s}$ \\
\hline 8 & $163.4, \mathrm{C}$ & & $163.3, \mathrm{C}$ & & 163.2, C & & $162.6, \mathrm{C}$ & \\
\hline 9 & $99.9, \mathrm{C}$ & & $99.9, \mathrm{C}$ & & $99.9, \mathrm{C}$ & & $99.2, \mathrm{C}$ & \\
\hline 10 & $137.6, \mathrm{C}$ & & $136.8, \mathrm{C}$ & & $134.8, \mathrm{C}$ & & $138.6, \mathrm{C}$ & \\
\hline 11 & $68.8, \mathrm{CH}$ & $4.66, \operatorname{td}(5.2,5.2)$ & $68.5, \mathrm{CH}$ & $5.01, \mathrm{~s}$ & $198.3, \mathrm{C}$ & & $173.9, \mathrm{C}$ & \\
\hline 12 & $64.8, \mathrm{CH}_{2}$ & $\begin{array}{l}3.62 \text {, ddd }(11.3,5.3,5.3) \\
3.51 \text {, ddd }(11.3,5.3,5.3)\end{array}$ & 173.4, C & & $65.9, \mathrm{CH}_{2}$ & $4.57, \mathrm{~d}(4.7)$ & $17.9, \mathrm{CH}_{3}$ & $2.29, \mathrm{~s}$ \\
\hline $6-\mathrm{OCH}_{3}$ & $56.0, \mathrm{CH}_{3}$ & $3.88, \mathrm{~s}$ & $56.0, \mathrm{CH}_{3}$ & $3.84, \mathrm{~s}$ & $56.0, \mathrm{CH}_{3}$ & $3.87, \mathrm{~s}$ & $55.8, \mathrm{CH}_{3}$ & $3.80, \mathrm{~s}$ \\
\hline $8-\mathrm{OH}$ & & 11.37, s & & $11.22, \mathrm{~s}$ & & $11.03, \mathrm{~s}$ & & $11.21, \mathrm{~s}$ \\
\hline $11-\mathrm{OH}$ & & $5.50, \mathrm{~d}(4.7)$ & & & & & & \\
\hline $12-\mathrm{OH}$ & & $4.81, \mathrm{t}(5.2)$ & & & & $5.28, \mathrm{t}(5.0)$ & & \\
\hline
\end{tabular}

a Data were measured at $600 \mathrm{MHz}\left({ }^{1} \mathrm{H}\right)$ and $150 \mathrm{MHz}\left({ }^{13} \mathrm{C}\right) \cdot{ }^{\mathrm{b}}$ Data were measured at $500 \mathrm{MHz}\left({ }^{1} \mathrm{H}\right)$ and $125 \mathrm{MHz}\left({ }^{13} \mathrm{C}\right)$. 

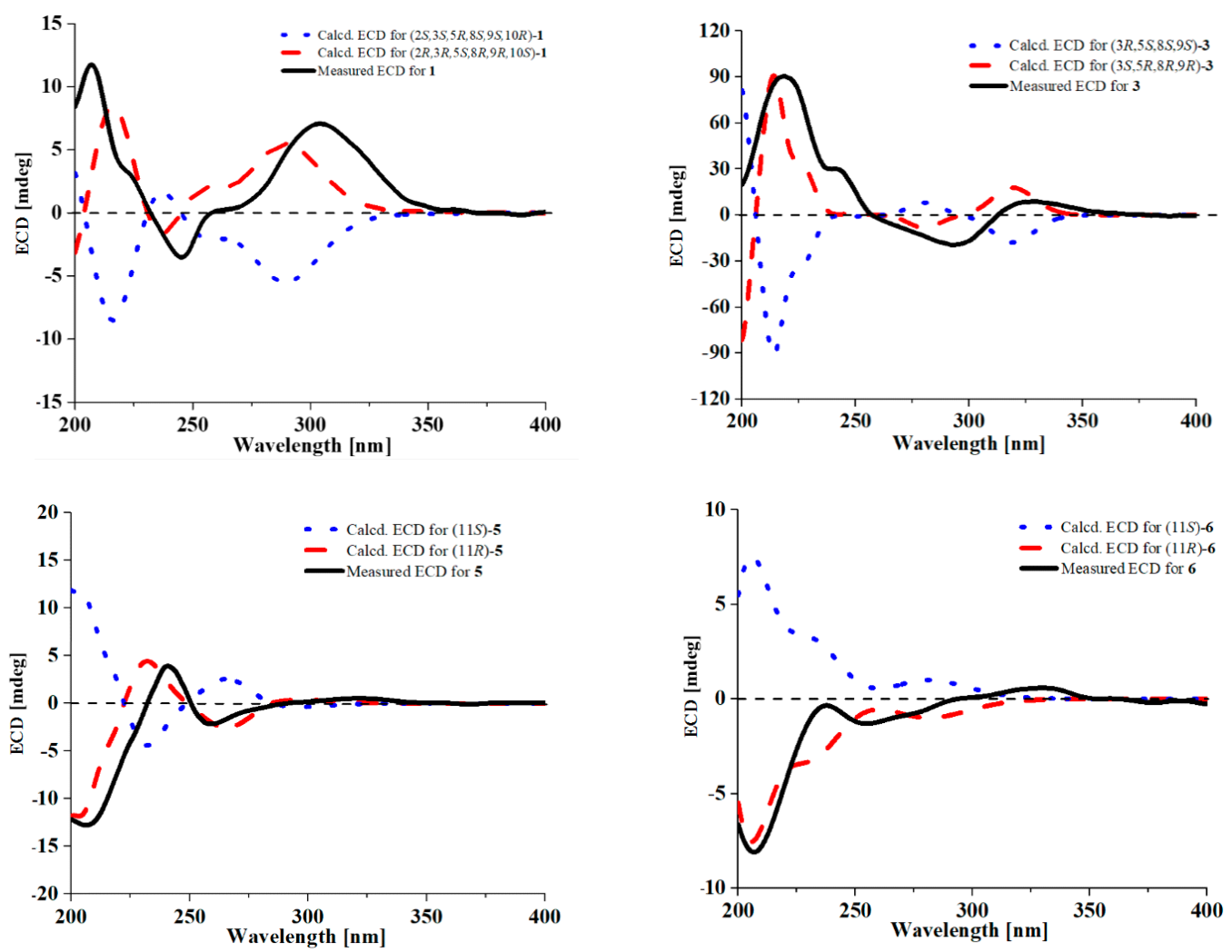

Figure 4. Measured and calculated ECD spectra for 1, 3, 5 and 6.
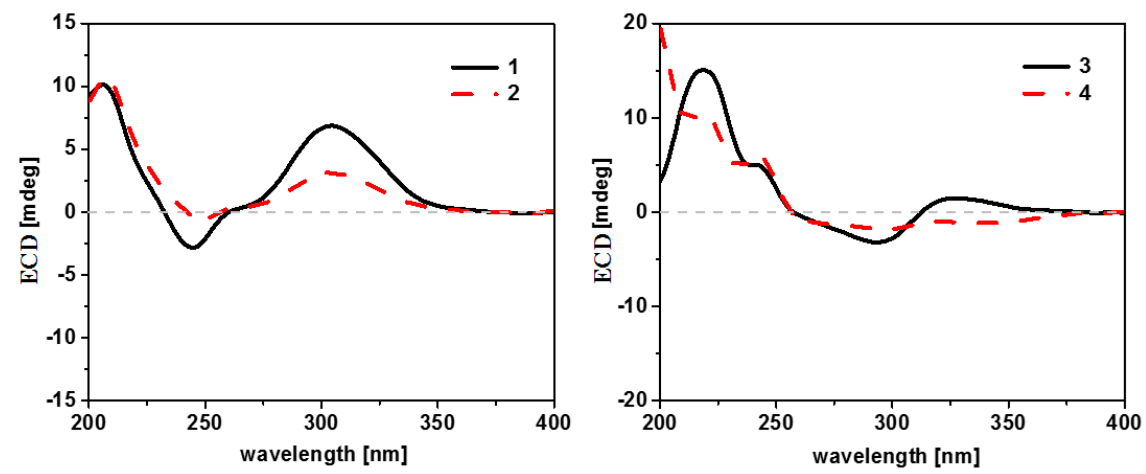

Figure 5. ECD spectra for 1-4.

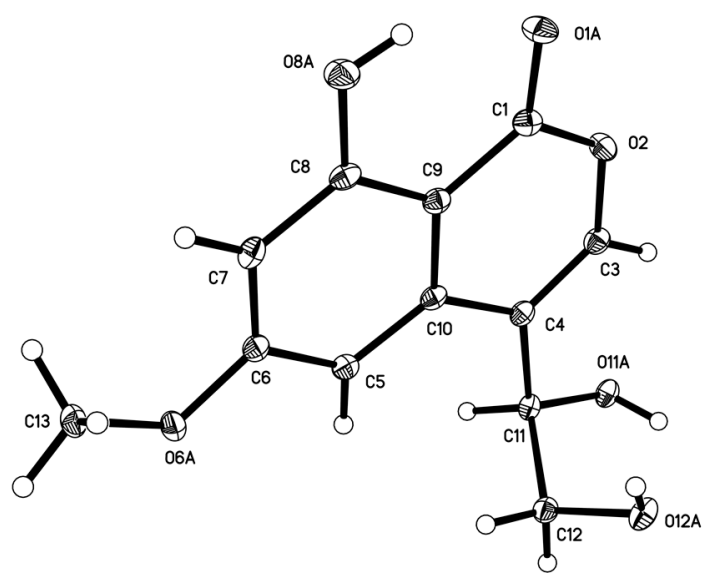

Figure 6. ORTEP diagram of 5. 
Compound 7 was obtained as a white powder. Its molecular formula was determined as $\mathrm{C}_{12} \mathrm{H}_{10} \mathrm{O}_{6}$ according to its HRESIMS peak at $\mathrm{m} / \mathrm{z} 249.0408[\mathrm{M}-\mathrm{H}]^{-}$(Figure S58G), which was only two hydrogen atoms less than that of $\mathbf{5}$. The difference observed in the NMR spectra of $\mathbf{7}$ and $\mathbf{5}$ was that the signals for hydroxymethine $\left(\delta_{\mathrm{C} / \mathrm{H}} 68.8 / 4.66\right)$ in 5 were replaced by the signal of a carbonyl group $\left(\delta_{\mathrm{C}-11} 198.3\right)$ in 7 (Table 2, Figures S45-S49). The HMBC (Figure S50) correlations from H-3 $\left(\delta_{\mathrm{H}} 8.47\right)$ and $\mathrm{H}-12\left(\delta_{\mathrm{H}}\right.$ 4.57 ) to $C-11$ further confirmed the structure of 7 which was name myrothelactone $C$ (Figure 2).

The molecular formula of compound 8 was determined as $\mathrm{C}_{12} \mathrm{H}_{10} \mathrm{O}_{6}$ on the basis of its HRESIMS peak at $m / z 249.0407[\mathrm{M}-\mathrm{H}]^{-}$(Figure $\left.\mathrm{S} 58 \mathrm{H}\right)$, which is an isomer of 7 . Analysis of its ${ }^{1} \mathrm{H}$ and ${ }^{13} \mathrm{C}$ NMR spectra showed that 8 also had the same isocoumarin scaffold, whose difference is the replacement of carbonyl $\left(\delta_{\mathrm{C}} 198.3\right)$, hydroxymethyl $\left(\delta_{\mathrm{C}} 65.9, \delta_{\mathrm{H}} 4.57 / 5.28\right)$ and sp ${ }^{2}$ methine $\left(\delta_{\mathrm{C}} 153.1, \delta_{\mathrm{H}} 8.47\right)$ signals in 7 by two sp ${ }^{2}$ non-protonated carbons $\left(\delta_{C} 173.9,151.0\right)$ and methyl $\left(\delta_{C} 17.9, \delta_{H} 2.29\right)$ signals in 8 (Table 2, Figures S51-S55). The HMBC correlations from H-12 $\left(\delta_{\mathrm{H}} 2.29\right)$ to C-3 $\left(\delta_{\mathrm{C}} 151.0\right)$ and C-4 $\left(\delta_{C}\right.$ 118.7) suggested the methyl substitution at C-3 (Figure 2 and Figure S56). The chemical shift of the carboxyl signal $\left(\delta_{C} 173.9\right)$ together with $2 D$ NMR data indicated the carboxyl substitution at $C-4$. The structure of myrothelactone D (8) was therefore determined (Figure 2).

The $\alpha$-glucosidase inhibitory activity of $\mathbf{1}-\mathbf{1 3}$ was preliminarily investigated. Compounds $\mathbf{1}-\mathbf{5}, \mathbf{7}$, 9 and 10 exhibited inhibitory activity against the human-sourced $\alpha$-glucosidase recombinant expressed in Saccharomyces cerevisiae [31-33] with $\mathrm{IC}_{50}$ values of 0.50, 0.66, 0.058, 0.20, 0.32, 0.036, 0.026 and $0.37 \mathrm{mM}$, while the $\mathrm{IC}_{50}$ value of positive control acarbose was $0.47 \mathrm{mM}$. Due to the low activity, the deeper investigation of the mechanism and type of enzymatic inhibition as well as the binding mode were not done.

\section{Experimental Section}

\subsection{General Experimental Procedures}

Optical rotations were measured using a JASCO P-1020 digital polarimeter (JASCO Corporation, Tokyo, Japan). UV spectra were obtained on a Beckman DU 640 spectrophotometer (Beckman Coulter, Inc., Brea, CA, USA). CD data were performed using a JASCO J-815 spectropolarimeter (JASCO Corporation, Tokyo, Japan). IR spectra were obtained on a Nicolet Nexus 470 spectrophotometer (Thermo Nicolet Corporation, Madison, WI, USA) as KBr discs. NMR spectra were recorded on a Varian System 500 spectrometer (Varian, Palo Alto, CA, USA) or a Bruker Avance 600 spectrometer (Bruker, Fallanden, Switzerland) using residual solvent signals for referencing and chemical shifts were recorded as $\delta$ values. HRESIMS spectra were measured using the Q-TOF ULTIMA GLOBAL GAA076 LC mass spectrometer (Waters Asia, Ltd., Singapore). Semi-preparative HPLC was performed using an ODS column (YMC-pack ODS-A, $10 \mathrm{~mm} \times 250 \mathrm{~mm}, 5 \mu \mathrm{m}, 4.0 \mathrm{~mL} / \mathrm{min}$, Kyoto, Japan). TLC and column chromatography (CC) were performed on plates pre-coated with silica gel $\mathrm{GF}_{254}(10-40 \mu \mathrm{m}$, Qingdao Marine Chemical Factory, Qingdao, China) and Sephadex LH-20 (Amersham Biosciences, Uppsala, Sweden), respectively. Vacuum-liquid chromatography (VLC) utilized silica gel H (Qingdao Marine Chemical Factory).

\subsection{Collection and Phylogenetic Analysis}

The fungus OUCMDZ-2784 was isolated from Apocynum venetum (Apocynaceae) collected from the estuary of Yellow River, Dongying, China. The leaves of the plant were washed with tap water and sterile distilled water in sequence. Then, it was cut into small pieces, which were then put into a centrifuge tubes filled with different concentrations of sucrose solution. These tubes were centrifuged at $1200 \mathrm{rpm}$ for $20 \mathrm{~min}$. Four zones were separated by improved discontinuous sucrose gradient centrifugation. The interface between the third and the fourth bands was deposited on a PDA (200 $\mathrm{g}$ potato, $20 \mathrm{~g}$ glucose, $20 \mathrm{~g}$ agar per liter of sea water) plate containing chloramphenicol $(100 \mu \mathrm{g} / \mathrm{mL})$ as a bacterial inhibitor and was then cultured at $28{ }^{\circ} \mathrm{C}$ for 3 days. A single colony was transferred to PDA agar media and was identified as Myrothecium sp. according to its morphological characteristics and $18 \mathrm{~S}$ rRNA gene sequences (GenBank accession No. KF977010). 


\subsection{Cultivation and Extraction}

Fungus OUCMDZ-2784 was prepared on PDA agar medium. Spores were incubated at $28^{\circ} \mathrm{C}$ for $48 \mathrm{~h}$ on a rotary shaker with shaking at $120 \mathrm{rpm}$ in a $500 \mathrm{~mL}$ cylindrical flask containing $150 \mathrm{~mL}$ liquid medium (20 g maltose, $20 \mathrm{~g}$ mannitol, $10 \mathrm{~g}$ glucose, $3 \mathrm{~g}$ yeast extract, $10 \mathrm{~g}$ monosodium glutamate per liter of sea water). The cultures were transferred to $350 \times 1000 \mathrm{~mL}$ Erlenmeyer flasks and each containing $300 \mathrm{~mL}$ liquid fermentation media ( $1 \mathrm{~g}$ peptone, $10 \mathrm{~g}$ soluble starch per liter of sea water, $\mathrm{pH}$ 7.0). The flasks were incubated at room temperature under static conditions for 30 days. The cultures were extracted three times by EtOAc and the combined EtOAc extracts were dried in vacuo to yield $20.1 \mathrm{~g}$ of extract.

\subsection{Purification}

The extract ( $20.1 \mathrm{~g})$ was fractionated by VLC, eluting with a step gradient of $\mathrm{CH}_{2} \mathrm{Cl}_{2}$-petroleum ether (50-100\%) and $\mathrm{MeOH}-\mathrm{CH}_{2} \mathrm{Cl}_{2}(0-50 \%)$ and five fractions (Fr.1-Fr.5) were collected. Fraction 2 (3.2 g) was subjected to Sephadex LH-20 chromatography eluting with $\mathrm{CH}_{2} \mathrm{Cl}_{2} / \mathrm{MeOH}$ (1:1) to afford three subfractions (Fr.2.1-Fr.2.3). Fr.2.1 (1.0 g) was further purified by HPLC on an ODS column $\left(80 \% \mathrm{MeOH} / \mathrm{H}_{2} \mathrm{O}\right)$ to give compounds $1\left(25.2 \mathrm{mg}, t_{\mathrm{R}} 6.3 \mathrm{~min}\right)$ and $3\left(30.1 \mathrm{mg}, t_{\mathrm{R}} 10.2 \mathrm{~min}\right)$. Fr.2.2 $(50.2 \mathrm{mg})$ was purified by HPLC on an ODS column $\left(60 \% \mathrm{MeOH} / \mathrm{H}_{2} \mathrm{O}\right)$ to yield compounds 11 $\left(3.5 \mathrm{mg}, t_{\mathrm{R}} 10.4 \mathrm{~min}\right)$ and 8 ( $\left.3.3 \mathrm{mg}, t_{\mathrm{R}} 15.2 \mathrm{~min}\right)$. Fr.2.3 (46.3 mg) was purified by HPLC on an ODS column $\left(60 \% \mathrm{MeOH} / \mathrm{H}_{2} \mathrm{O}\right)$ to yield compounds $12\left(5.1 \mathrm{mg}, t_{\mathrm{R}} 12.6 \mathrm{~min}\right)$ and $13\left(12.0 \mathrm{mg}, t_{\mathrm{R}} 16.4 \mathrm{~min}\right)$. Fraction 3 (3.8 g) was separated into three subfractions (Fr.3.1-Fr.3.3) by Sephadex LH-20 eluting with $\mathrm{MeOH}-\mathrm{CH}_{2} \mathrm{Cl}_{2}$ (1:1). Fr.3.1 (0.5 g) was purified by semi preparative HPLC on an ODS column (85\% $\left.\mathrm{MeOH} / \mathrm{H}_{2} \mathrm{O}\right)$ to yield compound $2\left(36.2 \mathrm{mg}, t_{\mathrm{R}} 10.2 \mathrm{~min}\right)$. Fr.3.2 $(1.1 \mathrm{~g})$ was separated by silica gel VLC column eluting with $\mathrm{CH}_{2} \mathrm{Cl}_{2}$-petroleum (2:1) to yield compounds $\mathbf{1 0}(100.3 \mathrm{mg}$ ) and $\mathbf{5}$ (200.8 mg). Fr.3.3 $(0.5 \mathrm{~g})$ was further purified by Sephadex LH-20 eluting with $\mathrm{MeOH}$ to yield compound 9 (15.3 mg). Fraction $4(1.8 \mathrm{~g})$ was separated into three subfractions (Fr.4.1-Fr.4.3) by Sephadex LH-20 eluting with MeOH. Fr.4.1 (0.6 g) was further purified by semi preparative HPLC on an ODS column (85\% $\left.\mathrm{MeOH} / \mathrm{H}_{2} \mathrm{O}\right)$ to yield compound $4\left(34.3 \mathrm{mg}, t_{\mathrm{R}} 12.2 \mathrm{~min}\right)$. Fr.4.2 $(0.2 \mathrm{~g})$ was further purified by semi preparative HPLC on an ODS column $\left(50 \% \mathrm{MeOH} / \mathrm{H}_{2} \mathrm{O}\right)$ to yield compound $7\left(6.0 \mathrm{mg}, t_{\mathrm{R}} 12.7 \mathrm{~min}\right)$. Fr.4.3 $(0.3 \mathrm{~g})$ was purified by HPLC on an ODS column $\left(40 \% \mathrm{MeOH} / \mathrm{H}_{2} \mathrm{O}\right)$ to yield compound 6 $\left(5.8 \mathrm{mg}, t_{\mathrm{R}} 10.6 \mathrm{~min}\right)$.

Myrothecisin A (1): pale yellow oil; $[\alpha]_{\mathrm{D}}^{20}+9.0\left(c\right.$ 0.1, $\left.\mathrm{CHCl}_{3}\right) ; \mathrm{UV}(\mathrm{MeOH}) \lambda_{\max }(\log \varepsilon) 212(4.13), 237$ (3.60), 305 (3.93) nm; ECD $(0.002 \mathrm{M}, \mathrm{MeOH}) \lambda_{\max }(\Delta \varepsilon) 207(+1.69), 244(-0.51), 304(+1.06) \mathrm{nm}$; IR (KBr) $v_{\max } 3443,2926,1719,1635,1372,1267 \mathrm{~cm}^{-1} ;{ }^{1} \mathrm{H}$ and ${ }^{13} \mathrm{C}$ NMR data, see Table $1 ;$ HRESIMS $\mathrm{m} / \mathrm{z}$ $469.2188[\mathrm{M}+\mathrm{Na}]^{+}$(calcd for $\left.\mathrm{C}_{25} \mathrm{H}_{34} \mathrm{O}_{7} \mathrm{Na}, 469.2197\right)$.

Myrothecisin B (2): pale yellow oil; $[\alpha]_{\mathrm{D}}^{20}+70.1\left(\right.$ c 0.1, $\left.\mathrm{CHCl}_{3}\right) ; \mathrm{UV}(\mathrm{MeOH}) \lambda_{\max }(\log \varepsilon) 211$ (4.10), 238 (3.62), $305(3.88) \mathrm{nm}$; ECD $(0.002 \mathrm{M}, \mathrm{MeOH}) \lambda_{\max }(\Delta \varepsilon) 207(+1.62), 249(-0.09), 305(+0.49) \mathrm{nm}$; IR (KBr) $v_{\max } 3424,2940,1733,1638,1460,1371,1263 \mathrm{~cm}^{-1} ;{ }^{1} \mathrm{H}$ and ${ }^{13} \mathrm{C}$ NMR data, see Table 1 ; HRESIMS $\mathrm{m} / \mathrm{z}$ 469.2200 [M + Na] $]^{+}$(calcd for $\left.\mathrm{C}_{25} \mathrm{H}_{34} \mathrm{O}_{7} \mathrm{Na}, 469.2197\right)$.

Myrothecisin C (3): pale yellow oil; $[\alpha]_{\mathrm{D}}^{20}+63.5\left(\right.$ c 0.1, $\left.\mathrm{CHCl}_{3}\right)$; UV (MeOH) $\lambda_{\max }(\log \varepsilon) 212(4.09), 239$ (3.65), 307 (3.81) nm; ECD (0.002 M, MeOH) $\lambda_{\max }(\Delta \varepsilon) 219$ (+2.29), 293 (-0.49), 327 (+0.22) nm; IR (KBr) $v_{\max } 3480,2936,1732,1612,1373,1254 \mathrm{~cm}^{-1} ;{ }^{1} \mathrm{H}$ and ${ }^{13} \mathrm{C}$ NMR data, see Table 1 ; HRESIMS $\mathrm{m} / \mathrm{z}$ 453.2238 [M + Na] ${ }^{+}$(calcd for $\mathrm{C}_{25} \mathrm{H}_{34} \mathrm{O}_{6} \mathrm{Na}, 453.2248$ ).

Myrothecisin D (4): pale yellow oil; $[\alpha]_{\mathrm{D}}^{20}+20.0\left(c 0.1, \mathrm{CHCl}_{3}\right)$; UV (MeOH) $\lambda_{\max }(\log \varepsilon) 203(4.16), 224$ (3.56), 300 (3.86) nm; ECD (0.002 M, MeOH) $\lambda_{\max }(\Delta \varepsilon) 220(+1.57), 242(+0.92), 295(-0.27) \mathrm{nm} ; \mathrm{IR}$ (KBr) $v_{\max } 2928,1718,1621,1370,1264,1027 \mathrm{~cm}^{-1} ;{ }^{1} \mathrm{H}$ and ${ }^{13} \mathrm{C}$ NMR data, see Table $1 ;$ HRESIMS $\mathrm{m} / \mathrm{z}$ 411.2139 $[\mathrm{M}+\mathrm{Na}]^{+}$(calcd for $\left.\mathrm{C}_{23} \mathrm{H}_{32} \mathrm{O}_{5} \mathrm{Na}, 411.2142\right)$.

Myrothelactone A (5): colorless crystal; melting point (mp) $174-175^{\circ} \mathrm{C} ;[\alpha]_{\mathrm{D}}^{20}-36.0(c 0.1, \mathrm{MeOH}) ; \mathrm{UV}$ $(\mathrm{MeOH}) \lambda_{\max }(\log \varepsilon) 246(3.82), 328(3.19) \mathrm{nm} ; \mathrm{ECD}(0.004 \mathrm{M}, \mathrm{MeOH}) \lambda_{\max }(\Delta \varepsilon) 206.5(-0.22), 241$ 
(+0.24), $259(-0.27) \mathrm{nm}$; IR (KBr) $v_{\max } 3747,3630,3159,2959,1668,1558,1398,1237 \mathrm{~cm}^{-1} ;{ }^{1} \mathrm{H}$ and ${ }^{13} \mathrm{C}$ NMR data, see Table 2; HRESIMS $m / z 251.0563[\mathrm{M}-\mathrm{H}]^{-}$(calcd for $\mathrm{C}_{12} \mathrm{H}_{11} \mathrm{O}_{6}, 251.0561$ ).

Myrothelactone B (6): white powder; $\mathrm{mp} 169-171{ }^{\circ} \mathrm{C} ;[\alpha]_{\mathrm{D}}^{20}-30.0(c 0.1, \mathrm{MeOH}) ; \mathrm{UV}(\mathrm{MeOH}) \lambda_{\max }(\log$ ع) 245 (3.81), $328(3.17) \mathrm{nm}$; ECD $(0.004 \mathrm{M}, \mathrm{MeOH}) \lambda_{\max }(\Delta \varepsilon) 206.5(-0.78), 241(+0.24), 259(-0.13)$ $\mathrm{nm} ; \mathrm{IR}(\mathrm{KBr}) v_{\max } 3749,2922,1681,1651,1619,1459,1399 \mathrm{~cm}^{-1} ;{ }^{1} \mathrm{H}$ and ${ }^{13} \mathrm{C}$ NMR data, see Table 2; HRESIMS $m / z 265.0355[\mathrm{M}-\mathrm{H}]^{-}$(calcd for $\mathrm{C}_{12} \mathrm{H}_{9} \mathrm{O}_{7}, 265.0354$ ).

Myrothelactone C (7): white powder; $\mathrm{mp} 160-161{ }^{\circ} \mathrm{C}$; UV (MeOH) $\lambda_{\max }(\log \varepsilon) 228$ (3.91), 263 (3.43), 325 (3.16) nm; IR (KBr) $v_{\max } 3750,3675,3615,1736,1651,1558,1540,1399 \mathrm{~cm}^{-1} ;{ }^{1} \mathrm{H}$ and ${ }^{13} \mathrm{C}$ NMR data, see Table 2; HRESIMS $m / z 249.0408$ [M - H] $]^{-}$(calcd for $\mathrm{C}_{12} \mathrm{H}_{9} \mathrm{O}_{6}, 249.0405$ ).

Myrothelactone D (8): white powder; $\mathrm{mp} 219-221^{\circ} \mathrm{C}$; UV (MeOH) $\lambda_{\max }(\log \varepsilon) 231$ (3.92), 263 (3.45), 325 (3.16) $\mathrm{nm}$; IR (KBr) $v_{\max } 3749,3673,3445,3197,1716,1682,1539,1457,1399 \mathrm{~cm}^{-1} ;{ }^{1} \mathrm{H}$ and ${ }^{13} \mathrm{C}$ NMR data, see Table 2; HRESIMS $m / z 249.0407$ [M - H] $]^{-}$(calcd for $\mathrm{C}_{12} \mathrm{H}_{9} \mathrm{O}_{6}, 249.0405$ ).

\subsection{X-ray Structure Determination of Compound $\mathbf{5}$}

Compound 5 was obtained as a colorless needles crystal with molecular formula $\mathrm{C}_{12} \mathrm{H}_{12} \mathrm{O}_{6}$. Orthorhombic, space group $P 2{ }_{1}{ }_{2}{ }_{2}{ }_{1}, a=4.9041(2) \AA, b=13.8470(5) \AA, c=15.7443(6) \AA, \alpha=90.00^{\circ}, \beta$ $=90.00^{\circ}, \gamma=90.00^{\circ}, V=1069.15(7) \AA 33, Z=4, D_{\text {calcd }}=1.567 \mathrm{Mg} / \mathrm{m}^{3}, \mu=1.089 \mathrm{~mm}^{-1}, F(000)=528$, crystal size $0.30 \mathrm{~mm} \times 0.18 \mathrm{~mm} \times 0.15 \mathrm{~mm}, T=293(2) \mathrm{K}$. A total of 1478 unique reflections $\left(2 \theta<50^{\circ}\right)$ were collected on a CCD area detector diffractometer with graphite monochromated $\mathrm{Cu} K \alpha$ radiation $(\lambda=1.54178 \AA$ ). The structure was solved by direct methods (SHELXS-97) and expanded using Fourier techniques (SHELXL-97). The final cycle of full-matrix least squares refinement was based on 1478 unique reflections $\left(2 \theta<50^{\circ}\right)$ and 165 variable parameters and converged with unweighted and weighted agreement factors of $R_{1}=0.0326, \mathrm{w} R_{2}=0.0885$ and $R=0.0880$ for $I>2 \operatorname{sigma}(I)$ data. Absolute structure parameter: $-0.2(2)$. The deposited number of compound 5 in the Cambridge Crystallographic Data Centre is 980155.

\section{6. $\alpha$-Glucosidase Inhibitory Assays}

The human-sourced $\alpha$-glucosidase was recombinant expressed in the yeast Saccharomyces cerevisiae and the inhibitory effects of compounds 1-13 were tested using p-nitrophenyl- $\alpha$-D-glucopyranoside (pNPG) as substrate [31-33]. The sample was dissolved in sodium phosphate buffer (PBS, pH 6.8) at three concentrations. $10 \mu \mathrm{L}$ of the sample solution, $20 \mu \mathrm{L}$ of $2.5 \mathrm{mM}$ pNPG solution (in phosphate buffer) and $20 \mu \mathrm{L}$ of PBS were mixed in a 96-well microplate and incubated at $37^{\circ} \mathrm{C}$ for $5 \mathrm{~min}$. A volume of $10 \mu \mathrm{L}$ of $\alpha$-glucosidase diluted to $0.2 \mathrm{U} / \mathrm{mL}$ by $0.01 \mathrm{M}$ PBS was then added to each well. After incubating at $37^{\circ} \mathrm{C}$ for $15 \mathrm{~min}$, the absorbance at $405 \mathrm{~nm}$ was recorded by a Spectra max 190 micro plate reader (Molecular Devices Inc., San Jose, CA, USA). The blank was prepared by adding phosphate buffer instead of the $\alpha$-glucosidase and the positive control was acarbose. Blank readings (no enzyme) were subtracted from each well and results were compared to the control. The inhibition $(\%)$ was calculated as $\left[1-\left(\mathrm{OD}_{\text {drug }} / \mathrm{OD}_{\text {blank }}\right)\right] \times 100 \%$. The $\mathrm{IC}_{50}$ value was calculated as the compound concentration that is required for $50 \%$ inhibition and the $\mathrm{IC}_{50}$ value of acarbose was $0.47 \mathrm{mM}$.

\section{Conclusions}

This study revealed eight new fungal NPs, meroterpenoids $\mathbf{1 - 4}$ and isocoumarinoids $\mathbf{5}-\mathbf{8}$, from the culture of the salt-tolerant plant-associated fungus Myrothecium sp. OUCMDZ-2784. The new compounds 1-5 and 7 exhibited $\alpha$-glucosidase inhibitory activity. Combined with bioactive NPs from mangrove-derived fungi [34-38], the results indicated that fungi living in the salt-tolerant plants are an important biological resources for new and bioactive NPs. 
Supplementary Materials: The following are available online at http:/ /www.mdpi.com/1660-3397/16/10/363/ s1, Figures S1-S4: DFT-optimized structures for low-energy conformers of compounds 1, 3, 5 and 6, Figures S5-S11: NMR spectra of compound 1 in DMSO- $d_{6}$, Figures S12-S18: NMR spectra of compound 2 in DMSO- $d_{6}$, Figures S19-S25: NMR spectra of compound 3 in DMSO- $d_{6}$, Figures S26-S32: NMR spectra of compound 4 in DMSO- $d_{6}$, Figures S33-S38: NMR spectra of compound 5 in DMSO- $d_{6}$, Figures S39-S44: NMR spectra of compound 6 in DMSO- $d_{6}$, Figures S45-S50: NMR spectra of compound 7 in DMSO- $d_{6}$, Figures S51-S56: NMR spectra of compound 8 in DMSO- $d_{6}$, Figure S57: ${ }^{1} \mathrm{H}$ - and ${ }^{13} \mathrm{C}-\mathrm{NMR}$ spectra of compounds 9-13 in DMSO- $d_{6}$, Figure S58: HRESI-MS spectra of compounds 1-8, Figure S59: ESI-MS spectra of compounds 9-13, Table S1: ${ }^{1} \mathrm{H}$ and ${ }^{13} \mathrm{C}$ NMR data for compounds $\mathbf{9 - 1 3}$ in DMSO- $d_{6}$.

Author Contributions: Y.X. performed the most experiments; C.W. prepared the draft of the manuscript; H.L. tested the $\alpha$-glucosidase inhibitory activity; G.Z. performed the ECD calculations; P.F. checked the data; L.W. revised the manuscript; W.Z. designed and supervised the research and revised the final version.

Funding: This research was funded by the NSFC (Nos. 81561148012, U1501221, 81741150, U1606403), the 100 Leading Talents of Guizhou Province (fund for W. Zhu), the science and technology project of Guizhou (Grant No. QKHT Z-2014-4007) and the academician workstation of Guizhou (Grant No. QKH YSZ-2015-4009).

Conflicts of Interest: The authors declare no conflict of interest.

\section{References}

1. Aly, A.H.; Debbab, A.; Proksch, P. Fifty years of drug discovery from fungi. Fungal Divers. 2011, 50, 3-19. [CrossRef]

2. Bladt, T.T.; Frisvad, J.C.; Knudsen, P.B.; Larsen, T.O. Anticancer and antifungal compounds from Aspergillus, Penicillium and other filamentous fungi. Molecules 2013, 18, 11338-11376. [CrossRef] [PubMed]

3. Khan, A.A.; Bacha, N.; Ahmad, B.; Lutfullah, G.; Farooq, U.; Cox, R.J. Fungi as chemical industries and genetic engineering for the production of biologically active secondary metabolites. Asian Pac. J. Trop. Biomed. 2014, 4, 859-870. [CrossRef]

4. Rateb, M.E.; Ebel, R. Secondary metabolites of fungi from marine habitats. Nat. Prod. Rep. 2011, 28, $290-344$. [CrossRef] [PubMed]

5. Bugnia, T.S.; Ireland, C.M. Marine-derived fungi: A chemically and biologically diverse group of microorganisms. Nat. Prod. Rep. 2004, 21, 143-163. [CrossRef] [PubMed]

6. Xu, L.; Meng, W.; Cao, C.; Wang, J.; Shan, W.; Wang, Q. Antibacterial and antifungal compounds from marine fungi. Mar. Drugs 2015, 13, 3479-3513. [CrossRef] [PubMed]

7. Moghadamtousi, S.Z.; Nikzad, S.; Kadir, H.A.; Abubakar, S.; Zandi, K. Potential antiviral agents from marine fungi: An overview. Mar. Drugs 2015, 13, 4520-4538. [CrossRef] [PubMed]

8. Strobel, G.; Daisy, B.; Castillo, U.; Harper, J. Natural products from endophytic microorganisms. J. Nat. Prod. 2004, 67, 257-268. [CrossRef] [PubMed]

9. Borges, W.S.; Borges, K.B.; Bonato, P.S.; Said, S.; Pupo, M.T. Endophytic fungi: natural products, enzymes and biotransformation reactions. Curr. Org. Chem. 2009, 13, 1137-1163. [CrossRef]

10. Nisa, H.; Kamili, A.N.; Nawchoo, I.A.; Shafi, S.; Shameem, N.; Bandh, S.A. Fungal endophytes as prolific source of phytochemicals and other bioactive natural products: A review. Microb. Pathog. 2015, 82, 50-59. [CrossRef] [PubMed]

11. Tan, R.X.; Zou, W.X. Endophytes: A rich source of functional metabolites. Nat. Prod. Rep. 2001, 18, 448-459. [CrossRef] [PubMed]

12. Sun, K.; Li, Y.; Guo, L.; Wang, Y.; Liu, P.; Zhu, W. Indole diterpenoids and isocoumarin from the fungus, Aspergillus flavus, isolated from the prawn, Penaeus vannamei. Mar. Drugs 2014, 12, 3970-3981. [CrossRef] [PubMed]

13. Zhu, G.; Kong, F.; Wang, Y.; Fu, P.; Zhu, W. Cladodionen, a cytotoxic hybrid polyketide from the marine-derived Cladosporium sp. OUCMDZ-1635. Mar. Drugs 2018, 16, 71. [CrossRef] [PubMed]

14. Wang, Y.; Zheng, J.; Liu, P.; Wang, W.; Zhu, W. Three new compounds from Aspergillus terreus PT06-2 grown in a high salt medium. Mar. Drugs 2011, 9, 1368-1378. [CrossRef] [PubMed]

15. Wang, Y.; Lu, Z.; Sun, K.; Zhu, W. Effects of high salt stress on secondary metabolites from marine-derived fungus Spicaria elegans. Mar. Drugs 2011, 9, 535-542. [CrossRef] [PubMed]

16. Wang, Y.; Wang, L.; Zhuang, Y.; Kong, F.; Zhang, C.; Zhu, W. Phenolic polyketides from the co-cultivation of marine-derived Penicillium sp. WC-29-5 and Streptomyces fradiae 007. Mar. Drugs 2014, 12, 2079-2088. [CrossRef] [PubMed] 
17. Chinese Pharmacopeia Committee of Ministry of Public Health of the People's Republic of China. Chinese Pharmacopeia 2000; Chemical and Technical Press: Beijing, China, 2000; p. 170.

18. Shaanxi Provincial and Municipal Collaborative Group for Prevention and Treatment of Coronary Heart Diseases. Clinical observation and pharmacological experiment of Apocynum venetum root in the treatment of heart failure. Shaanxi Med. J. 1974, 5, 10-14.

19. Isaka, M.; Punya, J.; Lertwerawat, Y.; Tanticharoen, M.; Thebtaranonth, Y. Antimalarial activity of macrocyclic trichothecenes isolated from the fungus Myrothecium verrucaria. J. Nat. Prod. 1999, 62, 329-331. [CrossRef] [PubMed]

20. Fu, Y.; Wu, P.; Xue, J.; Wei, X. Cytotoxic and antibacterial quinone sesquiterpenes from a Myrothecium fungus. J. Nat. Prod. 2014, 77, 1791-1799. [CrossRef] [PubMed]

21. Fu, Y.; Wu, P.; Xue, J.; Li, H.; Wei, X. Myrothecols G and H, two new analogues of the marine-derived quinone sesquiterpene Penicilliumin A. Mar. Drugs 2015, 13, 3360-3367. [CrossRef] [PubMed]

22. Hsu, Y.H.; Hirota, A.; Shima, S.; Nakagawa, M.; Nozaki, H.; Tada, T.; Nakayama, M. Structure of myrocin C, a new diterpene antibiotic produced by a strain of Myrothecium sp. Agric. Biol. Chem. 1987, 51, 3455-3457. [CrossRef]

23. Zou, X.; Niu, S.; Ren, J.; Li, E.; Liu, X.; Che, Y. Verrucamides A-D, antibacterial cyclopeptides from Myrothecium verrucaria. J. Nat. Prod. 2011, 74, 1111-1116. [CrossRef] [PubMed]

24. Nakashima, K.; Tomida, J.; Hirai, T.; Morita, Y.; Kawamura, Y.; Inoue, M. Tubakialactones A-E, new polyketides from the endophytic fungus Tubakia sp. ECN-111. Tetrahedron Lett. 2017, 58, 2248-2251. [CrossRef]

25. Rukachaisirikul, V.; Rodglin, A.; Sukpondma, Y.; Phongpaichit, S.; Buatong, J.; Sakayaroj, J. Phthalide and isocoumarin derivatives produced by an Acremonium sp. isolated from a mangrove Rhizophora apiculata. J. Nat. Prod. 2012, 75, 853-858. [CrossRef] [PubMed]

26. Kornsakulkarn, J.; Thongpanchang, C.; Lapanun, S.; Srichomthong, K. Isocoumarin glucosides from the scale insect fungus Torrubiella tenuis BCC 12732. J. Nat. Prod. 2009, 72, 1341-1343. [CrossRef] [PubMed]

27. Tanaka, A.K.; Sato, C.; Shibata, Y.; Kobayashi, A.; Yamashita, K. Growth promoting activities of sclerotinin A and its analogs. Agric. Biol. Chem. 1974, 38, 1311-1315. [CrossRef]

28. Kimura, Y.; Nakadoi, M.; Nakajima, H.; Hamasaki, T.; Nagai, T.; Kohmoto, K.; Shimada, A. Structure of sescandelin-B, a new metabolite produced by the fungus Sesquicillium candelabrum. Agric. Biol. Chem. 1991, $55,1887-1888$.

29. Zhao, J.; Feng, J.; Tan, Z.; Liu, J.; Zhao, J.; Chen, R.; Xie, K.; Zhang, D.; Li, Y.; Yu, L.; et al. Stachybotrysins A-G, phenylspirodrimane derivatives from the fungus Stachybotrys chartarum. J. Nat. Prod. 2017, 80, 1819-1826. [CrossRef] [PubMed]

30. Berova, N.; Bari, L.D.; Pescitelli, G. Application of electronic circular dichroism in configurational and conformational analysis of organic compounds. Chem. Soc. Rev. 2007, 36, 914-931. [CrossRef] [PubMed]

31. Kong, F.; Zhao, C.; Hao, J.; Wang, C.; Wang, W.; Huang, X.; Zhu, W. New $\alpha$-glucosidase inhibitors from a marine sponge-derived fungus, Aspergillus sp. OUCMDZ-1583. RSC Adv. 2015, 5, 68852-68863. [CrossRef]

32. Wang, C.; Guo, L.; Hao, J.; Wang, L.; Zhu, W. $\alpha$-Glucosidase inhibitors from the marine-derived fungus Aspergillus flavipes HN4-13. J. Nat. Prod. 2016, 79, 2977-2981. [CrossRef] [PubMed]

33. Shim, Y.-J.; Doo, H.-K.; Ahn, S.-Y.; Kim, Y.-S.; Seong, J.-K.; Park, I.-S.; Min, B.-H. Inhibitory effect of aqueous extract from the gall of Rhus chinensis on alpha-glucosidase activity and postprandial blood glucose. J. Ethnopharmacol. 2003, 85, 283-287. [CrossRef]

34. Lin, Z.; Zhu, T.; Fang, Y.; Gu, Q.; Zhu, W. Polyketides from Penicillium sp. JP-1, an endophytic fungus associated with the mangrove plant Aegiceras corniculatum. Phytochemistry 2008, 69, 1273-1278. [CrossRef] [PubMed]

35. Lu, Z.; Zhu, H.; Fu, P.; Wang, Y.; Zhang, Z.; Lin, H.; Liu, P.; Zhuang, Y.; Hong, K.; Zhu, W. Cytotoxic polyphenols from the marine-derived fungus Penicillium expansum. J. Nat. Prod. 2010, 73, 911-914. [CrossRef] [PubMed]

36. Wang, J.; Lu, Z.; Liu, P.; Wang, Y.; Li, J.; Hong, K.; Zhu, W. Cytotoxic polyphenols from the fungus Penicillium expansum 091006 endogenous with the mangrove plant Excoecaria agallocha. Planta Med. 2012, 78, 1861-1866. [PubMed] 
37. Kong, F.; Wang, Y.; Liu, P.; Dong, T.; Zhu, W. Thiodiketopiperazines from the marine-derived fungus Phoma sp. OUCMDZ-1847. J. Nat. Prod. 2014, 77, 132-137. [CrossRef] [PubMed]

38. Wang, L.; Han, X.; Zhu, G.; Wang, Y.; Chairoungdua, A.; Piyachaturawat, P.; Zhu, W. Polyketides from the endophytic fungus Cladosporium sp. isolated from the mangrove plant Excoecaria agallocha. Front. Chem. 2018, 6, 344. [CrossRef] [PubMed] 